\title{
Bimbingan Konseling Islam bagi Perilaku Peserta Didik Madrasah Tsanawiyah Negeri 1 Kota Cirebon
}

\author{
Asep Kurniawan \\ Program Studi Manajemen Pendidikan Islam, Fakultas Ilmu Tarbiyah dan Keguruan, \\ IAIN Syekh Nurjati Cirebon \\ asepqurniawan.ak@gmail.com
}

\begin{abstract}
Abstrak
Bimbingan dan Konseling Islam selama ini masih belum banyak diterapkan di lembaga pendidikan. Padahal hal ini berfungsi membantu peserta didik untuk berperilaku yang baik. Penelitian ini bertujuan untuk mengetahui pengaruh Bimbingan Konseling Islam terhadap perilaku peserta didik di MTsN 1 Kota Cirebon. Jenis penelitian ialah kuantitatif. Populasinya ialah 301 peserta didik MTsN 1 Kota Cirebon 2018-2019 dengan sampel 177. Instrumen pengumpulan data ialah kuesioner. Teknik analisis data: uji validitas, reliabilitas, normalitas, linearitas, dan regresi dengan bantuan SPSS for Windows 24.0. Temuan penelitian: (1) terdapat pengaruh yang sedang Bimbingan Konseling Islam terhadap Perilaku Individu peserta didik. (2) Terdapat pengaruh yang cukup pada Bimbingan Konseling Islam terhadap perilaku sosial peserta didik. (3) Terdapat pengaruh yang sedang pada Bimbingan Konseling Islam terhadap perilaku individu dan sosial peserta didik.
\end{abstract}

Kata Kunci: Bimbingan Konseling Islam; Perilaku; Peserta Didik.

\section{PENDAHULUAN}

Sekolah seharusnya dapat membantu peserta didik untuk menyelesaikan persoalan pembelajaran peserta didik dan membantunya dalam proses pendewasaan diri. Perubahanperubahan baik ini bisa ditinjau dari perubahan tingkah laku positif pada diri peserta didik. Tingkah laku adalah berbagai tindakan yang dilakukan oleh seseorang sebab adanya pengaruh dari lingkungan.

Ada sejumlah faktor yang bisa memberikan pengaruh terhadap tingkah laku seseorang yakni faktor situasional, spiritual, sosio-psikologis, dan biologis (Mobarok, 2002, hlm. 45). Diantara keempat faktor tersebut, faktor spiritual dan sosiopsikologis adalah hal yang dominan ada di lembaga pendidikan. Hasil penelitian Garza, Brañas, Espín, dan Neuman (2013) menemukan sejumlah fakta bahwa (1) individu yang tidak beragama membuat keputusan lebih dekat dengan perilaku egois dibandingkan dengan 
mereka yang tekun dalam beragama. (2) Di kalangan umat Katolik, intensitas religiusitas adalah variabel kunci yang memengaruhi perilaku sosial sejauh individu yang aktif secara religius pada umumnya lebih pro-sosial daripada yang tidak aktif.

Faktor spiritual adalah faktor yang berkaitan dengan rohani yang dimaksudkan untuk mendapatkan kebutuhan ruhani. Diantara sejumlah motivasi spiritual yang penting bagi kehidupan manusia ialah motivasi agama. Di dalam Islam, hal tersebut disebabkan manusia secara fitrah mempunyai potensi keberagamaan. Sebagaimana disebutkan di dalam al-Qur'an surat al-Rum ayat 30: "Maka hadapkanlah wajahmu dengan lurus kepada agama Allah, (tetaplah pada) fitrah Allah yang sudah menciptakan manusia menurut fitrah itu. Tidak ada perubahan pada fitrah Allah. (Itulah) agama yang lurus, namun sebagian besar manusia tidak mengetahui”.

Keberadaan sekolah yang bertanggungjawab dalam perkembangan siswa secara maksimal diharapkan dapat merubah tingkah laku individual peserta didik menjadi pribadi yang lebih baik dan lebih dewasa lagi yang selaras dengan tujuan pendidikan yakni pendidikan sekolah dimaksudkan untuk menghasilkan perubahan tingkah laku positif pada diri peserta didik yang sedang berkembang ke arah kedewasaannya. Disamping itu dari tingkahlaku individu yang mesti dikembangkan dengan maksimal oleh sekolah, peserta didik harus dididik untuk bersosialisi dengan masyarakat.

Eksistensi sekolah memiliki dua aspek penting, yakni aspek individua dan sosial. Di satu sisi, eksistensi sekolah berperan mempengaruhi dan menciptakan keadaan yang memungkinkan perkembangan pribadi siswa dengan maksimal. Di sisi lain, sekolah berperan mendidik agar siswa berkontribusi terhadap masyarakat. Untuk itu pendidikan di sekolah mempunyai sumbangsih yang besar bagi pembentukan sikap, perilaku dan karakter peserta didik.

Demi merealisasikan peran sekolah sebagai tempat belajar peserta didik secara umum dan merubah perilakunya menjadi lebih baik lagi, ada sejumlah aktivitas yang dilakukan sekolah selain dari pada proses pembelajaran yakni adanya layanan bimbingan dan konseling Islam.Bimbingan konseling Islam dilakukan secara sistematis, berkesinambungan, dan terarah kepada semua siswa agar ia bisa mengembangkan fitrah atau potensi beragama yang dimilikinya dengan maksimal melalui internalisasi nilai yang termuat di dalam al-Qur'an dan Hadis Rasulullah saw ke dalam dirinya, sehingga dia bisa hidup sejalan dengan bimbingan al-Qur'an dan Hadis. Dalam sejumlah studi menjelaskan bahwa bimbingan konseling keagamaan seperti ini diakui sangat dibutuhkan karena nilai spiritual dapat memainkan peran penting dalam kehidupan manusia. Peserta didik dapat menemukan makna kehidupan yang sesungguhnya dan dapat dijadikan solusi permasalahan yang ada.

Bimbingan konseling mempunyai sejumlah fungsi, diantaranya ialah fungsi pemahaman. Dalam fungsi ini, bimbingan dan konseling memunculkan pemahaman mengenai sesuatu kepada peserta didik. Pemahaman tersebut menyangkut pemahaman kepada diri siswa, lingkungan sekolah, dan keluarga, serta pemahaman mengenai 
lingkungan dari peserta didik itu sendiri. Dari fungsi ini diharapkan siswa bisa tumbuh dengan maksimal menjadi siswa yang mandiri dan utuh.

Disamping fungsi pemahaman, bimbingan konseling juga mempunyai fungsi adaptasi. Melalui fungsi ini peserta didik dibantu untuk beradaptasi dengan lingkungan sehingga mereka bisa bersikap yang semestinya dan membantu peserta didik untuk mengembangkan kegiatan pendidikan yang tepat untuknya.

Melalui sentuhan Islam dalam bimbingan dan konseling maka peserta didik menjadi pribadi yang mandiri, utuh dan mempunyai tingkah laku yang selaras dengan ajaran Islam berdasarkan al-Quran dan Hadis. Penelitian Tuchili (2017, hlm. 88-94) menemukan bahwa siswa yang mendapatkan layanan bimbingan dan konseling menunjukkan perilaku yang dapat diterima dalam berbagai aspek kehidupan mereka.

Hakekatnya secara ideal, bimbingan dan konseling seyogyanya diselenggarakan dari sejak di pendidikan usia dini sampai perguruan tinggi. Namun, dilihat dari sisi keperluan praktis yang esensial selaras dengan tingkat perkembangan kejiwaan siswa, dimana muncul kecanggungan-kecanggungan jiwa yang bisa mengganggu perkembangan hidupnya ialah siswa di tingkatan sekolah menengah pertama dan sekolah menengah atas. Di level sekolah menengah inilah dibutuhkan pengaturan dan organisasi yang tetap dalam implementasi bimbingan dan konseling tersebut. Untuk itu, studi ini diarahkan di MTs N 1 Kota Cirebon.

Bimbingan dan konseling memiliki peranan dan fungsi yang besar di institusi pendidikan untuk membangun perilaku dan kepribadian peserta didik. Namun, sekarang wujud pelayanan ini banyak yang belum menyadarinya, baik itu dari peserta didik itu sendiri ataupun pendidik. Umumnya orang banyak menilai bahwa bimbingan dan konseling adalah hal yang ditakuti oleh sejumlah peserta didik sebab sebagian besar mereka menilainya sebagai program pemberian peringatan atau hukuman dikarenakan suatu pelanggaran. Padahal, lebih dari itu bimbingan konseling adalah program yang bisa menolong peserta didik dalam memecahkan persoalan.

Di sejumlah sekolah, bimbingan dan konseling telah mulai diintegrasikan ke dalam bahan ajar. Namun, program itu belum dipandang penting sebagaimana pelajaran yang lainnya sehingga tidak menunjukkan perubahan perilaku siswa yang baik dari program tersebut, padahal tujuannya adalah untuk membantu peserta didik memecahkan permasalahan dan membantunya untuk berperilaku baik.Melalui penerapan bimbingan konseling dengan pendekatan Islam, berbagai kegiatannya diarahkan kepada perubahan perilaku lahiriyah ataupun batiniyah sejalan dengan tujuan yang diharapkan tercapai berdasarkan al-Quran dan Hadist.

\section{METODE PENELITIAN}

Jenis penelitian ini yang dipakai ialah kuantitatif dengan populasi peserta didik MTs Negeri 1 Kota Cirebon 2018-2019, yang terdiri dari 301 peserta didik. Dengan teknik sampling simple random sampling didapatkan sampel 177 peserta didik. Variabel independen ialah Bimbingan Konseling Islam. Variabel dependen ialah perilaku individu 
dan perilaku sosial. Instrumen pengumpulan data menggunakan kuesioner dengan 24 pernyataan, setiap pernyataan memiliki 5 pilihan jawaban dengan rentang skor 1 sampai 5 . Skor harapan terkecil ialah 24, sementara total skor harapan terbesar ialah 120. Teknik analisis data ditempuh melalui uji validitas, reliabilitas, normalitas, linearitas, dan regresi dengan menggunakan program SPSS for Windows versi 24.0.

\section{HASIL DAN PEMBAHASAN}

\section{Bimbingan Konseling Islam}

Data Bimbingan Konseling Islam yang diperoleh dari para responden sejumlah 177 secara kuantitatif memperlihatkan bahwa skor minimal yang diperoleh ialah 47 dan skor total maksimalnya ialah 116. Rentang jumlah skor range yang mungkin didapatkan ialah $116-47=69$. Interval kelas memakai formula $\mathrm{k}=1+3,3 \log \mathrm{n}$ (k ialah jumlah kelas interval dan $\mathrm{n}$ ialah jumlah data), maka didapatkan $\mathrm{k}=1+3,3 \log 177=8,418$ dan digenapkan menjadi 8 . Artinya, jumlah kelas ialah 8 . Selanjutnya panjang interval kelas ialah $\mathrm{R} / \mathrm{k}=(116-47) / 8=8,625$ atau dibulatkan menjadi 9 .

Data tersebut bisa digolongkan ke dalam kelas interval Bimbingan Konseling Islam yaitu:

Tabel 1. Data Hasil Kuesioner Bimbingan Konselin
\begin{tabular}{|l|r|}
\hline Statistik Bimbingan Konseling Islam \\
\hline Malid & 177 \\
Mean & 0 \\
Std. Error of Mean & 95.07 \\
Median & .893 \\
Mode & 97.00 \\
Std. Deviation & 106 \\
Variance & 11.887 \\
Range & 141.296 \\
Minimum & 69 \\
Maximum & 47 \\
Sum & 116 \\
Sumber: Data diolah oleh peneliti 2019
\end{tabular}

Tabel 1 menggambarkan bahwa hasil angket mengenai Bimbingan Konseling Islam dengan total responden 177 mempunyai nilai mean 95.07, median 97,00, modus 106, range 69, nilai terkecil 47 dan nilai tertinggi 116. Data hasil kuesioner dari peserta didik juga mempunyai distribusi frekuensi, yaitu: 
Tabel 2. Distribusi Frekuensi Bimbingan Konseling Islam Interval Bimbingan Konseling Islam

\begin{tabular}{|ll|r|r|r|r|}
\hline & Frequency & Percent & Valid Percent & $\begin{array}{c}\text { Cumulative } \\
\text { Percent }\end{array}$ \\
\hline Valid & $47-55$ & 2 & 1.1 & 1.1 & 1.1 \\
& $56-64$ & 1 & .6 & .6 & 1.7 \\
$65-73$ & 4 & 2.3 & 2.3 & 4.0 \\
$74-82$ & 16 & 9.0 & 9.0 & 13.0 \\
$83-92$ & 47 & 26.6 & 26.6 & 39.5 \\
$93-101$ & 48 & 27.1 & 27.1 & 66.7 \\
$102-110$ & 48 & 27.1 & 27.1 & 93.8 \\
$111-116$ & 11 & 6.2 & 6.2 & 100.0 \\
Total & 177 & 100.0 & 100.0 & \\
\hline
\end{tabular}

Sumber: Data diolah oleh peneliti 2019

Tabel 2 menunjukkan bahwa distribusi frekuensi terkecil ada pada kelas interval kedua (56 - 64) sebesar $0.6 \%$ atau 1 responden. Sementara itu, distribusi frekuensi tertinggi ada pada kelas interval keenam dan kelas interval ketujuh sebesar $27.1 \%$ atau 48 responden. Distribusi frekuensi terkecil ada pada kelas interval kedua (56 - 64) sejumlah 1 responden. Sementara distribusi frekuensi tertinggi ada pada kelas interval keenam (93 101) dan kelas interval ketujuh (102 - 110) sejumlah 48 responden.

Tahap berikutnya sesudah data dimasukkan dalam tabel distribusi frekuensi ialah menetapkan mutu Bimbingan Konseling Islam yakni sejalan dengan tabel 1 dengan ratarata 95.07 dibulatkan menjadi 95 , dan standar deviasi variabel $\mathrm{X}$ sejumlah 11.887 dibulatkan menjadi 12. Sesudah nilai rata-rata dan standar deviasi didapatkan, maka tahap berikutnya merubah skor mentah menjadi skor standar lima dengan formula114:

$$
\begin{aligned}
& \bar{X}+1.5 \times \text { SD }=95+(1.5 \times 12)=113 \\
& \bar{X}+0.5 \times \text { SD }=95+(0.5 \times 12)=101 \\
& \bar{X}-0.5 X \text { SD }=95-(0.5 \times 12)=89 \\
& \bar{X}-1.5 X \text { SD }=95-(1.5 \times 12)=77
\end{aligned}
$$

Berpijak pada kalkulasi tersebut didapatkan data interval dan data kualifikasi, yaitu:

Tabel 3. Kriteria Bimbingan Konseling Islam

\begin{tabular}{|l|l|c|c|c|}
\hline No. & \multicolumn{1}{|c|}{ Kriteria } & Interval & Jumlah & Prosentase \\
\hline 1. & Sangatbaik & $\geq 114$ & 4 & $2,3 \%$ \\
\hline 2. & Baik & $102-113$ & 55 & $31,1 \%$ \\
\hline 3. & Cukup & $90-101$ & 63 & $35,6 \%$ \\
\hline 4. & Kurang & $78-89$ & 43 & $24,3 \%$ \\
\hline 5. & Sangatkurang & $\leq 77$ & 12 & $6,8 \%$ \\
\hline & \multicolumn{3}{|l}{} \\
\hline
\end{tabular}


Berpijak tabel 3 di atas memperlihatkan bahwa Bimbingan Konseling Islam bisa didapatkan 4 responden atau 2,3\% responden dikatagorikan sangat baik, 31,1\% atau 55 responden dikatagorikan baik, 35,6\% atau 63 responden dikatagorikan cukup, 24,3\% atau 43 responden dikatagorikan kurang, dan 6,8\% atau 12 responden dikatagorikan sangat kurang. Oleh karena itu, Bimbingan Konseling Islam di MTsN 1 Kota Cirebon dapat dikategorikan cukup dengan rata-rata yang terletak pada interval 90-101 atau prosentase $35,6 \%$.

1. Perilaku Individu

Alat yang dipakai guna mengukur Perilaku Individu berupa kuesioner yang terdiri dari 11 pernyataan, yang setiap pernyataan memiliki 5 pilihan jawaban dengan rentang skor 1 sampai 5. Skor harapan terkecil ialah 11, sementara total skor harapan terbesar ialah 55. Berpijak pada total skor harapan ini bisa ditetapkan interval skor setiap kelas.

Data Perilaku Individu yang diperoleh dari responden sejumlah 177 secara kuantitatif memperlihatkan bahwa skor minimal yang diperoleh ialah 24 dan skor total maksimalnya ialah 55. Rentang jumlah skor maksimal yang mungkin didapatkan ialah 55-24=31. Interval kelas memakai formula $\mathrm{k}=1+3,3 \log \mathrm{n}$ ( $\mathrm{k}$ ialah jumlah kelas interval dan $\mathrm{n}$ ialah banyaknya data), maka didapatkan $\mathrm{k}=1+3,3 \log 177=8,418$ dan digenapkan menjadi 8 . Artinya, jumlah kelas ialah 8 . Selanjutnya panjang interval kelas ialah $\mathrm{R} / \mathrm{k}=(55-24) / 8=3,875$ digenapkan menjadi 4 .

Oleh karena itu, bisa dikatagorikan kelas interval Perilaku Individu, yaitu:

Tabel 4. Data Hasil Angket Perilaku Individu

\begin{tabular}{|l|r|}
\hline \multicolumn{2}{|c|}{ Statistik Perilaku Individu } \\
\hline N Valid $\quad$ Missing & 177 \\
Mean & 0 \\
Std. Error of Mean & 40.18 \\
Median & .457 \\
Mode & 41.00 \\
Std. Deviation & 41 \\
Variance & 6.083 \\
Range & 36.998 \\
Minimum & 31 \\
Maximum & 24 \\
Sum & 55 \\
\multicolumn{2}{|l|}{ Sumber: Data diolah oleh peneliti 2019}
\end{tabular}

Tabel 4 menggambarkan bahwa hasil angket mengenai Perilaku Individu dengan jumlah n maupun responden sejumlah 177 mempunyai nilai mean 40.18, median 41.00, 
modus 41, range 31, nilai terkecil 24 dan nilai terbesar 55.Data dari hasil kuesioner dari peserta didik ataupun responden juga memiliki distribusi frekuensi, yaitu:

Tabel 5. Distribusi Frekuensi Perilaku Individu

Interval Perilaku Individu

\begin{tabular}{|rr|r|r|r|r|}
\hline & & & & \multicolumn{2}{|c|}{$\begin{array}{c}\text { Cumulative } \\
\text { Percent }\end{array}$} \\
\hline Valid & $24-27$ & 7 & 4.0 & 4.0 & 4.0 \\
& $28-31$ & 9 & 5.1 & 5.1 & 9.0 \\
$32-35$ & 19 & 10.7 & 10.7 & 19.8 \\
$36-39$ & 42 & 23.7 & 23.7 & 43.5 \\
$40-43$ & 48 & 27.1 & 27.1 & 70.6 \\
$44-47$ & 31 & 17.5 & 17.5 & 88.1 \\
$48-51$ & 18 & 10.2 & 10.2 & 98.3 \\
$52-55$ & 3 & 1.7 & 1.7 & 100.0 \\
Total & 177 & 100.0 & 100.0 & \\
\hline
\end{tabular}

Sumber: Data diolah oleh peneliti 2019

Tabel 5 menunjukkan bahwa distribusi frekuensi terkecil terdapat pada kelas interval kedelapan (52 - 55) sebesar $1.7 \%$ atau 3 responden. Sementara distribusi frekuensi terbesar ada pada kelas interval kelima (40 - 43) sebesar 27.1\% atau 48 responden. Distribusi frekuensi terkecil ada pada kelas interval kedelapan (52 - 55) sejumlah 3 responden. Sementara distribusi frekuensi terbesar ada pada kelas interval kelima (40 - 43) sejumlah 48 responden.

Tahap berikutnya sesudah data dimasukkan dalam tabel distribusi frekuensi ialah menetapkan mutu Perilaku Individu yakni sejalan dengan tabel 4 rata-rata Y1, yaitu 40,18 digenapkan menjadi 40 dan standar deviasi variabel Y1, yaitu 6.083 digenapkan 6. Sesudah nilai rata-rata dan standar deviasi didapatkan, dipakai guna mengubah skor mentah menjadi skor standar lima dengan formula:

$$
\begin{aligned}
& \bar{X}+1,5 \times \mathrm{SD}=40+(1,5 \times 6)= \\
& \bar{X}+0,5 \times \mathrm{SD}=40+(0,5 \times 6)= \\
& \bar{X}-0,5 \times \mathrm{SD}=40-(0,5 \times 6)= \\
& \bar{X}-1,5 \times \mathrm{SD}=40-(1,5 \times 6)=
\end{aligned}
$$

Berdasarkan perhitungan data tersebut didapatkan data interval dan data kualifikasi, yaitu:

Tabel 6. Kriteria Perilaku Individu Peserta Didik

\begin{tabular}{|l|c|c|c|c|}
\hline No & Kriteria & Interval & Jumlah & Prosentase \\
\hline 1 & SangatBaik & $\geq 49$ & 15 & $8,5 \%$ \\
\hline 2 & Baik & $43-48$ & 46 & $26 \%$ \\
\hline 3 & Cukup & $37-42$ & 73 & $41,2 \%$ \\
\hline 4 & Kurang & $32-36$ & 27 & $15,3 \%$ \\
\hline 5 & SangatKurang & $\leq 31$ & 16 & $9 \%$ \\
\hline & Total & & 177 & $100 \%$ \\
\hline
\end{tabular}


Berpijak pada tabel 6 di atas memperlihatkan bahwa Perilaku Individu bisa didapatkan 8,5\% responden atau 15 responden dikatagorikan sangat baik, 26\% atau 46 responden dikatagorikan baik, $41,2 \%$ atau 73 responden dikatagorikan cukup, 15,3\% atau 27 responden dikatagorikan kurang, dan 9\% atau 16 responden dikatagorikan sangat kurang. Dengan demikian Perilaku Individu peserta didik di MTsN 1 Kota Cirebon dikatagorikan cukup dengan prosentase $41,2 \%$ dengan rata-rata pada interval $37-42$.

2. Perilaku Sosial

Alat yang dipakai guna mengukur Perilaku Sosial adalah kuesioner yang memuat 12 pernyataan, yang setiap pernyataan memiliki 5 pilihan jawaban dengan rentang skor 1 - 5. Skor harapan terkecil ialah 12. Sementara total skor harapan terbesar ialah 60. Berpijak pada total skor harapan ini, bisa ditetapkan interval skor setiap kelas.

Data Perilaku Sosial yang diperoleh dari responden sejumlah 177 secara kuantitatif memperlihatkan bahwa skor minimal yang diperoleh ialah 27 dan skor total maksimalnya ialah 60. Rentang jumlah skor maksimal yang mungkin didapatkan ialah $60-27=33$. Interval kelas memakai formula $\mathrm{k}=1+3,3 \log \mathrm{n}$, maka didapatkan $\mathrm{k}=1$ $+3,3 \log 177=8,418$ dan digenapkan menjadi 8 . Artinya, jumlah kelas ialah 8 . Selanjutnya panjang interval kelas ialah $\mathrm{R} / \mathrm{k}=(60-27) / 8=4,125$ dan selanjutnya digenapkan menjadi 4. Oleh karena itu, bisa dikatagorikan kelas interval Perilaku Sosial, yaitu:

Tabel 7. Data Hasil Kuesioner Perilaku Sosia
\begin{tabular}{|l|r|}
\hline N Valid & 177 \\
$\quad$ Missing & 0 \\
Mean & 49.79 \\
Std. Error of Mean & .488 \\
Median & 50.00 \\
Mode & 56 \\
Std. Deviation & 6.487 \\
Variance & 42.075 \\
Range & 33 \\
Minimum & 27 \\
Maximum & 60 \\
Sum & 8813 \\
\hline
\end{tabular} Sumber: Data diolah oleh peneliti 2019

Tabel 7 menggambarkan bahwa hasil kuesioner mengenai Perilaku Sosial dengan jumlah $\mathrm{n}$ atau responden sejumlah 177 mempunyai nilai mean 49,79, median 50,00, modus 56, range 33, nilai terkecil 27 dan nilai terbesar 60 . 
Data dari hasil kuesioner dari responden atau peserta didik juga memiliki distribusi frekuensi, yaitu:

Tabel 8. Distribusi Frekuensi Perilaku Sosial

\begin{tabular}{|r|r|r|r|r|}
\hline & Frequency & Percent & Valid Percent & Cumulative Percent \\
\hline Valid 27-30 & 2 & 1.1 & 1.1 & 1.1 \\
\hline $31-34$ & 2 & 1.1 & 1.1 & 2.3 \\
\hline $35-38$ & 8 & 4.5 & 4.5 & 6.8 \\
\hline $39-42$ & 11 & 6.2 & 6.2 & 13.0 \\
\hline $43-46$ & 25 & 14.1 & 14.1 & 27.1 \\
\hline $47-50$ & 41 & 23.2 & 23.2 & 50.3 \\
\hline $51-54$ & 31 & 17.5 & 17.5 & 67.8 \\
\hline $55-60$ & 57 & 32.2 & 32.2 & 100.0 \\
\hline Total & 177 & 100.0 & 100.0 & \\
\hline
\end{tabular}

Sumber: Data diolah oleh peneliti 2019

Tabel 8 menunjukkan bahwa distribusi frekuensi terkecil ada pada kelas interval pertama (27 - 30) dan kedua (31 - 34) sebesar 1,1\% atau sejumlah 2 responden. Sementara distribusi frekuensi tertinggi ada pada kelas interval kedelapan sebesar $32.2 \%$ atau sejumlah 57 responden. Distribusi frekuensi terkecil ada pada kelas interval pertama (27 - 30) dan kedua (31 - 34) sejumlah 2 responden. Sementara distribusi frekuensi terbesar ada pada kelas interval kedelapan sejumlah 57 responden.

Tahap berikutnya sesudah data dimasukkan dalam tabel distribusi frekuensi ialah menetapkan mutu Perilaku Sosial yakni sejalan dengan tabel 7 dengan rata-rata 49,79 digenapkan menjadi 50, dan standar deviasi variabel Y2 sejumlah 6,487 dibulatkan menjadi 6. Sesudah nilai rata-rata dan standar deviasi didapatkan, maka tahap berikutnya mengubah skor mentah menjadi skor standar lima dengan formula:

$$
\begin{aligned}
& \bar{X}+1.5 \times \text { SD }=50+(1.5 \times 6)= \\
& \bar{X}+0.5 \times \text { SD }=50+(0.5 \times 6)= \\
& \bar{X}-0.5 \text { XD }=50-(0.5 \times 6)= \\
& \bar{X}-1.5 \times \text { SD }=50-(1.5 \times 6)=
\end{aligned}
$$

Berlandaskan pada perhitungan tersebut didapatkan data interval dan data kualifikasi, yaitu:

Tabel 9. Kriteria Perilaku Sosial Peserta Didik

\begin{tabular}{|l|c|c|c|c|}
\hline No & Kriteria & Interval & Jumlah & Prosentase \\
\hline 1 & SangatBaik & $\geq 60$ & 4 & $2,3 \%$ \\
\hline 2 & Baik & $54-59$ & 60 & $33,9 \%$ \\
\hline 3 & Cukup & $48-53$ & 55 & $31,1 \%$ \\
\hline 4 & Kurang & $42-47$ & 37 & $20,9 \%$ \\
\hline 5 & SangatKurang & $\leq 41$ & 21 & $11,9 \%$ \\
\hline & Total & & 177 & $100 \%$ \\
\hline
\end{tabular}


Berpijak pada tabel 9 tersebut memperlihatkan bahwa Perilaku Sosial bisa didapatkan 2,3\% responden atau 4 responden dikatagorikan sangat baik, 33,9\% atau 60 responden dikatagorikan baik, $31,1 \%$ atau 55 responden dikatagorikan cukup, 20,9\% atau 37 responden dikatagorikan kurang, dan 11,9\% atau 21 responden dikatagorikan sangat kurang. Dengan demikian Perilaku Sosial peserta didik di MTs N 1 Kota Cirebon dapat dikatagorikan Baik dengan prosentase 33,9\% dengan rata-rata pada interval 54 - 59.

3. Perilaku Individu dan Sosial

Alat yang dipakai guna mengukur Perilaku Individu Sosial adalah kuesioner dengan 23 pernyataan, yang setiap pernyataan memiliki 5 pilihan jawaban dengan rentang skor 1 sampai 5. Skor harapan terkecil ialah 23, sementara total skor harapan terbesar ialah 115. Berlandaskan pada total skor harapan itu bisa ditetapkan interval skor setiap kelas.

Data Perilaku Individu dan Sosial yang diperoleh dari para responden sejumlah 177 secara kuantitatif memperlihatkan bahwa skor minimal yang diperoleh ialah 30 dan skor total maksimalnya ialah 56. Rentang jumlah skor maksimal yang mungkin didapatkan ialah 56- 30 $=26$. Interval kelas memakai formula $\mathrm{k}=1+3,3 \log \mathrm{n}$, maka didapatkan $\mathrm{k}=1+3,3 \log 177=8,418$ dan digenapkan menjadi 8 . Artinya, jumlah kelas ialah 8. Selanjutnya panjang interval kelas ialah $\mathrm{R} / \mathrm{k}=(56-30) / 8=3,375$ dan selanjutnya dibulatkan menjadi 3 .

Oleh karena itu bisa digolongkan kelas interval Perilaku Individu dan Sosial, yaitu:

Tabel 10. Data Hasil Angket Perilaku Individu dan Sosial Statistik Perilaku Individu dan Sosial

\begin{tabular}{|l|r|}
\hline N Valid & 177 \\
$\quad$ Missing & 0 \\
Mean & 44.98 \\
Std. Error of Mean & .433 \\
Median & 45.50 \\
Mode & 44 \\
Std. Deviation & 5.763 \\
Variance & 33.216 \\
Range & 27 \\
Minimum & 30 \\
Maximum & 56 \\
Sum & 7962 \\
\hline \multicolumn{2}{|l|}{ Sumber: Data diolah oleh peneliti 2019}
\end{tabular}


Tabel 10 menggambarkan bahwa hasil kuesioner mengenai Perilaku Individu dan Sosial Peserta Didik dengan jumlah n atau responden sejumlah 177 mempunyai nilai mean 44,98, median 45,50, modus 44, range 27, nilai terkecil 30 dan nilai terbesar 56 .

Data dari hasil kuesioner dari responden atau peserta didik juga memiliki distribusi frekuensi, yaitu:

Tabel 11. Distribusi Frekuensi Perilaku Individu dan Sosial Interval Perilaku Individu dan Sosial

\begin{tabular}{|c|r|r|r|r|}
\hline & Frequency & Percent & Valid Percent & $\begin{array}{c}\text { Cumulative } \\
\text { Percent }\end{array}$ \\
\hline Valid 29.5-34.5 & 11 & 6.2 & 6.2 & 6.2 \\
\hline $35-37.5$ & 10 & 5.6 & 5.6 & 11.9 \\
\hline $38-40.5$ & 20 & 11.3 & 11.3 & 23.2 \\
\hline $41-43.5$ & 24 & 13.6 & 13.6 & 36.7 \\
\hline $44-46.5$ & 38 & 21.5 & 21.5 & 58.2 \\
\hline $47-49.5$ & 33 & 18.6 & 18.6 & 76.8 \\
\hline $50-52.5$ & 29 & 16.4 & 16.4 & 93.2 \\
\hline $53-56.5$ & 12 & 6.8 & 6.8 & 100.0 \\
\hline Total & 177 & 100.0 & 100.0 & \\
\hline
\end{tabular}

Sumber: Data diolah oleh peneliti 2019

Pada tabel 11 menunjukkan bahwa distribusi frekuensi terkecil ada pada kelas interval kedua (35 - 37.5) sebesar 5,6 \% atau sebanyak 10 responden. Sementara distribusi frekuensi ada pada kelas interval kelima (44 - 46,5) sebesar $21.5 \%$ atau sebanyak 38 responden. Distribusi frekuensi terkecil ada pada kelas interval kedua (35 37.5) sejumlah 10 responden. Sementara distribusi frekuensi terbesar ada pada kelas interval kelima (44 - 46,5) sejumlah 38 responden.

Tahap berikutnya sesudah data dimasukkan dalam tabel distribusi frekuensi ialah menetapkan mutu Perilaku Individu dan Sosial peserta didik yakni sejalan dengan tabel 5.0 dengan rata-rata 44,98 dibulatkan menjadi 45 , dan standar deviasi variabel Y1, 2 sejumlah 5,763 dibulatkan menjadi 6.

Sesudah nilai mean dan standar deviasi didapatkan, maka tahap berikutnya mengubah skor mentah menjadi skor standar lima dengan formula:

$$
\begin{aligned}
& \bar{X}+1.5 \times \text { SD }=45+(1.5 \times 6)= \\
& \bar{X}+0.5 \times \text { SD }=45+(0.5 \times 6)= \\
& \bar{X}-0.5 \times \text { SD }=45-(0.5 \times 6)= \\
& X-1.5 \times \text { SD }=45-(1.5 \times 6)=
\end{aligned}
$$


28 Kurniawan - Bimbingan Konseling Islam ...

Berpijak pada perhitungan tersebut didapatkan data interval dan data kualifikasi, yaitu:

Tabel 12. Kriteria Perilaku Individu dan Sosial Peserta Didik

\begin{tabular}{|l|c|c|c|c|}
\hline No & Kriteria & Interval & Jumlah & Prosentase \\
\hline 1 & SangatBaik & $\geq 55$ & 4 & $2,3 \%$ \\
\hline 2 & Baik & $49-54.5$ & 47 & $26,6 \%$ \\
\hline 3 & Cukup & $43-48,5$ & 73 & $41,2 \%$ \\
\hline 4 & Kurang & $37-42,5$ & 35 & $19,8 \%$ \\
\hline 5 & SangatKurang & $\leq 36,5$ & 18 & $10,2 \%$ \\
\hline & Total & & 177 & $100 \%$ \\
\hline
\end{tabular}

Berpijak pada tabel 12 di atas memperlihatkan bahwa Perilaku Individu dan Sosial Peserta Didik bisa didapatkan 2,3\% responden atau 4 responden dikatagorikan sangat baik, 26,6\% atau 47 responden dikatagorikan baik, 41,2\% atau 73 responden dikatagorikan cukup, $19,8 \%$ atau 35 responden dikatagorikan kurang, dan 10,2\% atau 18 responden dikatagorikan sangat kurang. Dengan demikian Perilaku Individu dan Sosial peserta didik di MTsN 1 Kota Cirebon dapat dikategorikan cukup dengan prosentase $41,2 \%$ dengan rata-rata pada interval $43-48,5$.

\section{Uji Asumsi/ Uji Persyaratan Analisis}

1. Uji Normalitas

Pengujian normalitas ini ditujukan guna menemukan bahwa distribusi studi ini tidak menyimpang secara signifikan dari distribusi normal. Diantara cara untuk mengetahui nilai normalitas ialah dengan formula Kolmogrof Smirnov yang dalam hal ini dibantu memakai software SPSS for Windows 24.00.

Tabel 13. Hasil Uji Normalitas Perilaku Individu

$$
\text { One-Sample Kolmogorov-Smirnov Test }
$$

\begin{tabular}{|ll|r|}
\hline & & $\begin{array}{c}\text { Unstandardized } \\
\text { Residual }\end{array}$ \\
\hline Normal Parameters & \\
& Mean & 177 \\
Most Extreme Differences & Std. Deriation & .0000000 \\
& Absolute & 5.54147773 \\
& Positive & .046 \\
Kolmogoror-Smirnor: Z & Negative & .044 \\
Asymp. Sig. (2-tailed) & & -.046 \\
& & .606 \\
\hline a. Test distribution is Normal. & .857 \\
\hline
\end{tabular}


Tabel 14. Hasil Uji Normalitas Perilaku Sosial One-Sample Kolmogorov-Smirnov Test

\begin{tabular}{|c|c|c|}
\hline & & $\begin{array}{c}\text { Unstandardize } \\
\text { d Residual }\end{array}$ \\
\hline $\mathrm{N}$ & & 177 \\
\hline Normal Parameters ${ }^{a}$ & Mean & .0000000 \\
\hline & Std. Deviation & 5.86588770 \\
\hline Most Extreme & Absolute & .060 \\
\hline Differences & Positive & .042 \\
\hline & Negative & -.060 \\
\hline Kolmogorov-Smirno & & .796 \\
\hline Asymp. Sig. (2-tailed & & .551 \\
\hline a. Test distribution is & mal. & \\
\hline
\end{tabular}

Tabel 15. Hasil Uji Normalitas Perilaku Individu dan Sosial One-Sample Kolmogorov-Smirnov Test

\begin{tabular}{|c|c|c|}
\hline & & $\begin{array}{c}\text { Unstandardize } \\
\text { d Residual }\end{array}$ \\
\hline \multicolumn{2}{|l|}{$\mathrm{N}$} & 177 \\
\hline \multirow[t]{2}{*}{ Normal Parameters ${ }^{\mathrm{a}}$} & Mean & .0000000 \\
\hline & Std. Deviation & 5.12391342 \\
\hline Most Extreme & Absolute & .047 \\
\hline \multirow[t]{2}{*}{ Differences } & Positive & .023 \\
\hline & Negative & -.047 \\
\hline \multicolumn{2}{|c|}{ Kolmogorov-Smirnov Z } & .627 \\
\hline \multicolumn{2}{|l|}{ Asymp. Sig. (2-tailed) } & .827 \\
\hline \multicolumn{2}{|c|}{ a. Test distribution is Normal. } & \\
\hline
\end{tabular}

Berpijak pada uji normalitas dengan dasar penetapan keputusan probilitas dalam uji normalitas apabila nilai signifikansi $<0,05$, maka data dikatagorikan berdistribusi tidak normal, apabila nilai signifikansi > 0,05, maka data dikatagorikan berdistribusi normal. Berdasarkan seluruh uji normalitas nilai sig $>0,05$, maka data dikatagorikan berdistribusi normal. 
2. Uji Linearitas

Tabel 16. Hasil Uji Linearitas Variabel Perilaku Individu (Y1)

ANOVA Table

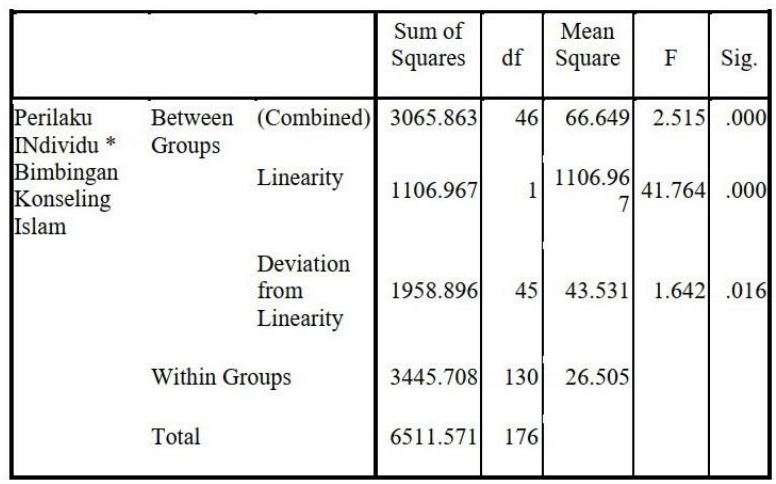

Berpijak pada tabel 16 tersebut, terungkap bahwa variabel Perilaku Individu mempunyai nilai $\mathrm{F}$ hitung =1,642. Dikatagorikan linear apabila F hitung < F tabel. F tabel bisa dicari pada tabel statistik pada taraf signifikansi 0,05. Untuk mencari $\mathrm{F}$ tabel mesti ditemukan nilai df1 dan df2, df1 = k-1 $(3-1)=2$, dan df2 = n-k $(177-2)=175$. Nilai F tabel sejumlah 3,048. Dengan demikian bisa diperoleh bahwa F hitung $<\mathrm{F}$ tabel $(1,642<3,048)$. Hal tersebut memperlihatkan bahwa ada hubungan linear yang signifikan antara variabel Bimbingan Konseling Islam (X) terhadap Perilaku Individu (Y1).

Tabel 17. Hasil Uji Linearitas Variabel Perilaku Sosial (Y2)

\begin{tabular}{|c|c|c|c|c|c|c|}
\hline & & $\begin{array}{l}\text { Sum of } \\
\text { Squares }\end{array}$ & df & $\begin{array}{l}\text { Mean } \\
\text { Square }\end{array}$ & $\mathrm{F}$ & Sig. \\
\hline $\begin{array}{l}\text { Perilaku Sosial } \\
* \text { Bimbingan } \\
\text { Konseling } \\
\text { Islam }\end{array}$ & $\begin{array}{l}\text { Between (Combined) } \\
\text { Groups } \\
\qquad \begin{array}{ll} & \text { Linearity } \\
& \\
& \text { Deviation } \\
& \text { Linearity } \\
\text { Within Groups }\end{array} \\
\text { Total }\end{array}$ & $\begin{array}{l}3688.067 \\
1349.345 \\
2338.722 \\
3717.199 \\
7405.266\end{array}$ & $\begin{array}{c}45 \\
130 \\
176\end{array}$ & $\begin{array}{r}80.175 \\
1349.34 \\
5 \\
51.972 \\
28.594\end{array}$ & $\begin{array}{r}2.804 \\
47.190\end{array}$ & $\begin{array}{l}.000 \\
.000 \\
.005\end{array}$ \\
\hline
\end{tabular}

Berpijak pada tabel 17 tersebut, terungkap bahwa variabel Perilaku Sosial mempunyai nilai $\mathrm{F}$ hitung $=1,81$. Disebut linear apabila $\mathrm{F}$ hitung $<\mathrm{F}$ tabel. $\mathrm{F}$ tabel bisa dicari pada tabel statistik pada signifikansi 0,05. Untuk menemukan $F$ tabel mesti diketahui dulu nilai df 1 dan df2, df1 = k-1 $(3-1)=2$, dan df $2=n-k(336-2)=334$. Nilai 
$\mathrm{F}$ tabel sejumlah 3,048. Dengan demikian bisa ditemukan bahwa $\mathrm{F}$ hitung $<\mathrm{F}$ tabel $(1,81<3,048)$. Hal tersebut memperlihatkan bahwa ada hubungan linear yang signifikan antara variabel Bimbingan Konseling Islam (X) terhadap Perilaku Sosial (Y2).

Tabel 18. Hasil Uji Linearitas Variabel Perilaku Individu dan Sosial (Y1,2)

\begin{tabular}{|c|c|c|c|c|c|c|c|}
\hline & & & $\begin{array}{l}\text { Sum of } \\
\text { Squares }\end{array}$ & df & $\begin{array}{c}\text { Mean } \\
\text { Square }\end{array}$ & $\mathrm{F}$ & Sig. \\
\hline \multirow{8}{*}{$\begin{array}{l}\text { Perilaku } \\
\text { Individu dan } \\
\text { Sosial * } \\
\text { Bimbingan } \\
\text { Konseling Islam }\end{array}$} & \multicolumn{2}{|c|}{ Between (Combined) } & 3014.390 & 46 & 65.530 & 3.009 & .000 \\
\hline & Groups & Linearity & & & 122515 & & \\
\hline & & & 1225.159 & 1 & 9 & 56.248 & .000 \\
\hline & & Deviation & & & & & \\
\hline & & from & 1789.231 & 45 & 39.761 & 1.825 & .005 \\
\hline & & Linearity & & & & & \\
\hline & \multicolumn{2}{|c|}{ Within Groups } & 2831.559 & 130 & 21.781 & & \\
\hline & \multicolumn{2}{|l|}{ Total } & 5845.949 & 176 & & & \\
\hline
\end{tabular}

Berpijak pada tabel 18 tersebut, terungkap bahwa variable Perilaku Sosial mempunyai nilai $\mathrm{F}$ hitung $=1,82$. Disebut linear apabila $\mathrm{F}$ hitung $<\mathrm{F}$ tabel. $\mathrm{F}$ table bias dilihat di table statistic pada signifikansi 0,05. Untuk mencari $F$ table mesti diketahui nilai df1 dan df2, df1 = k-1 $(3-1)=2$, dan df2 = n-k $(336-2)=334$. Nilai $\mathrm{F}$ table sejumlah 3,048. Dengan demikian bias ditemukan bahwa $F$ hitung $<F$ tabel $(1,82<$ 3,048). Hal tersebut memperlihatkan bahwa adanya hubungan linear yang signifikan antara variable Bimbingan Konseling Islam (X) terhadap Perilaku Individu dan Sosial (Y2).

\section{Pengujian Hipotesis}

1. Korelasi Bimbingan Konseling Islam (X) terhadap Perilaku Individu Peserta Didik (Y1) di MTsN 1 Kota Cirebon

Tabel 19. Hasil Korelasi Perilaku Individu

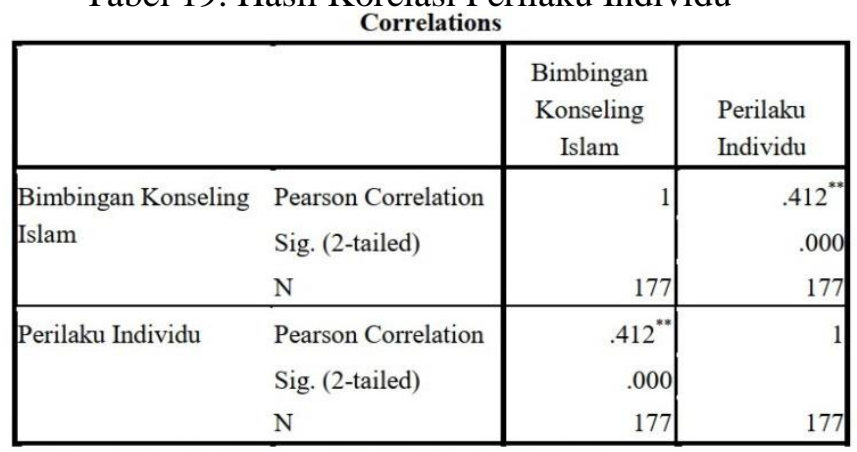

**. Correlation is significant at the 0.01 level (2-tailed). 
Berpijak pada output korelasi ini diperoleh $\mathrm{r}$ hasil atau Pearson correlation sejumlah 0,412. Hal tersebut memperlihatkan bahwa nilai ini ada pada interval nilai dari korelasi antara 0,40 - 0,70 dengan kekuatan hubungan yang dikatagorikan sedang atau cukup berarti.

Perumusan hipotesis yang pertama ialah sebagai berikut:

H0 : "tidak terdapat pengaruh bimbingan konseling Islam terhadap perilaku peserta didik".

H1 : "terdapat pengaruh bimbingan konseling Islam terhadap perilaku peserta didik".

Apabila nilai $r$ hasil $<\mathrm{r}$ table, maka $\mathrm{H} 0$ diterima dan $\mathrm{H} 1$ ditolak, namun jika $\mathrm{r}$ hasil > r table, maka $\mathrm{H} 1$ diterima dan $\mathrm{H} 0$ ditolak. Berpijak pada analisis terdapat $\mathrm{r}$ hasil sejumlah 0,412 dan nilai $r$ tabel bagi responden 177 sebesar dengan tingkat signifikansi $5 \%$ sejumlah 0,148, maka bisa ditemukan $r$ hasil $>\mathrm{r}$ tabel atau 0,412>0,148, maka $\mathrm{H} 1$ diterima dan H0 ditolak. Dengan hasil ini memperlihatkan terdapat pengaruh Bimbingan Konseling Islam terhadap perilaku individu peserta didik.

2. Korelasi Bimbingan Konseling Islam (X) terhadap Perilaku sosial (Y2) di MTs N 1 Kota Cirebon

Tabel 20. Hasil Korelasi Perilaku Sosial

Correlations

\begin{tabular}{|ll|r|r|}
\hline & $\begin{array}{c}\text { Bimbingan } \\
\text { Konseling } \\
\text { Islam }\end{array}$ & Perilaku Sosial \\
\hline Bimbingan Konseling & Pearson Correlation & 1 & $.427^{* *}$ \\
Islam & Sig. (2-tailed) & 177 & .000 \\
& $\mathrm{~N}$ & $.427^{* *}$ & 177 \\
\hline Perilaku Sosial & Pearson Correlation & .000 & 1 \\
& Sig. (2-tailed) & 177 & 177 \\
\hline
\end{tabular}

**. Correlation is significant at the 0.01 level (2-tailed).

Berpijak pada output korelasi di atas diperoleh $\mathrm{r}$ hasil atau Pearson correlation sejumlah 0,427. Hal tersebut memperlihatkan bahwa nilai ini ada diinterval nilai dari korelasi antara 0,40 - 0,70 dengan kekuatan hubungan dikatagorikan sedang atau cukup berarti.

Formulasi hipotesis yang pertama, yaitu:

H0 : "tidak terdapat pengaruh Bimbingan Konseling Islam terhadap Perilaku Sosial".

H1 : "terdapat pengaruh Bimbingan Konseling Islam terhadap Perilaku Sosial”.

Apabila nilai $r$ hasil < $r$ table, maka $\mathrm{H} 0$ diterima dan $\mathrm{H} 1$ ditolak, namun jika $\mathrm{r}$ hasil > r table, maka $\mathrm{H} 1$ diterima dan $\mathrm{H} 0$ ditolak. Berpijak pada analisis terdapat $\mathrm{r}$ hasil sejumlah 0,427 dan nilai $r$ tabel untuk responden sejumlah 177 dengan taraf signifikansi 
$5 \%$ sejumlah 0,148 , maka bisa ditemukan $r$ hasil $>\mathrm{r}$ tabel atau $0,427>0,148$, maka $\mathrm{H} 1$ diterima dan H0 ditolak. Melalui hasil ini memperlihatkan terdapat pengaruh Bimbingan Konseling Islam terhadap Perilaku Sosial peserta didik.

3. Korelasi Bimbingan Konseling Islam (X) terhadap Perilaku Individu dan Sosial Peserta Didik (Y1dan 2) di MTs N 1 Kota Cirebon

Tabel 21. Hasil Korelasi Perilaku Individu dan Sosial Peserta Didik

\begin{tabular}{|ll|r|r|}
\hline \multicolumn{1}{|c|}{ Correlations } & $\begin{array}{c}\text { Bimbingan } \\
\text { Konseling } \\
\text { Islam }\end{array}$ & \multicolumn{1}{c|}{ Y12 } \\
\hline Bimbingan Konseling & Pearson Correlation & 1 & $.458^{* *}$ \\
Islam & Sig. (2-tailed) & 177 & .000 \\
& N & $.458^{* *}$ & 177 \\
\hline Y12 & Pearson Correlation & .000 & 177 \\
& Sig. (2-tailed) & 177 & 177 \\
& N & & \\
& & & \\
\end{tabular}

**. Correlation is significant at the 0.01 level (2-tailed).

Berlandaskan pada output korelasi di atas diperoleh $r$ hasil atau Pearson correlation sejumlah 0,427 . Hal tersebut memperllihatkan bahwa nilai ini ada pada interval nilai dari korelasi antara 0,40 - 0,70 dengan kekuatan hubungan dikatagorikan sedang atau cukup berarti.

Formulasi hipotesis yang pertama, yaitu:

H0 : "tidak terdapat pengaruh Bimbingan Konseling Islam terhadap Perilaku Sosial". H1 : "terdapat pengaruh Bimbingan Konseling Islam terhadap Perilaku Sosial”.

Apabila nilai $\mathrm{r}$ hasil < $\mathrm{r}$ table, maka $\mathrm{H} 0$ diterima dan $\mathrm{H} 1$ ditolak, namun jika $\mathrm{r}$ hasil > r table, maka $\mathrm{H} 1$ diterima dan $\mathrm{H} 0$ ditolak. Beranalisis terdapat $\mathrm{r}$ hasil sejumlah 0,427 dan nilai $\mathrm{r}$ tabel untuk responden sejumlah 177 dengan tingkat signifikansi $5 \%$ sejumlah 0,148, maka bisa didapatkan $\mathrm{r}$ hasil > $\mathrm{r}$ tabel atau 0,427 >0,148, maka H1 diterima dan $\mathrm{H} 0$ ditolak. Melalui hasil ini memperlihatkan terdapat pengaruh Bimbingan Konseling Islam terhadap Perilaku Sosial peserta didik. 
34 | Kurniawan - Bimbingan Konseling Islam ...

4. Pengaruh Bimbingan Konseling Islam terhadap Perilaku Peserta Didik di MTs N 1 Kota Cirebon

a. Perilaku Individu

Tabel 22. Hasil Uji Regresi Perilaku Individu

\begin{tabular}{|c|c|c|c|c|c|c|c|c|c|}
\hline \multirow[b]{2}{*}{ Model } & \multirow[b]{2}{*}{$\mathrm{R}$} & \multirow[b]{2}{*}{$\begin{array}{c}\mathrm{R} \\
\text { Square }\end{array}$} & \multirow[b]{2}{*}{$\begin{array}{c}\text { Adjust } \\
\text { ed R } \\
\text { Square }\end{array}$} & \multirow[b]{2}{*}{$\begin{array}{c}\text { Std. Error } \\
\text { of the } \\
\text { Estimate }\end{array}$} & \multicolumn{5}{|c|}{ Change Statistics } \\
\hline & & & & & $\begin{array}{c}\text { R } \\
\text { Square } \\
\text { Change }\end{array}$ & $\begin{array}{c}\mathrm{F} \\
\text { Chang } \\
\mathrm{e}\end{array}$ & df1 & df2 & $\begin{array}{c}\text { Sig. F } \\
\text { Chang } \\
\text { e }\end{array}$ \\
\hline 1 & $.412^{\mathrm{a}}$ & .170 & .165 & 5.557 & .170 & 35.843 & 1 & 175 & .000 \\
\hline
\end{tabular}

1) Predictors: (Constant), BimbinganKonseling Islam

2) Dependent Variable: Perilaku Individu Kesimpulan:

1) Nilai $R$ adalah symbol dari koefisien korelasi sejumlah 0,412 .

2) Nilai $R$ Square memperlihatkan sejauh mana interaksi variable bebas (X) terhadap variable terikat (Y). Dari table ini bias ditemukan pengaruh Bimbingan Konseling Islam (X) terhadap Perilaku Peserta Didik (Y1) sejumlah 0,17 atau dapat dikatagorikan mempunyai pengaruh kontribusi $17 \%$ terhadap Perilaku Individu (Y1), lainnya dipengaruhi oleh faktor lain di luar variabel (X) atau variabel lain di luar penelitian ini ataupun dapat dikatakan variabel moderator sejumlah $83 \%$.

b. Perilaku Sosial Peserta Didik

Tabel 23. Hasil Uji Regresi Perilaku Sosial

Model Summary ${ }^{\text {b }}$

\begin{tabular}{|c|c|c|c|c|c|c|c|c|c|}
\hline \multirow[b]{2}{*}{ Model } & & \multirow[b]{2}{*}{$\begin{array}{c}\mathrm{R} \\
\text { Square }\end{array}$} & \multirow[b]{2}{*}{$\begin{array}{c}\text { Adjuste } \\
\text { d R } \\
\text { Square }\end{array}$} & \multirow[b]{2}{*}{$\begin{array}{l}\text { Std. Error } \\
\text { of the } \\
\text { Estimate }\end{array}$} & \multicolumn{5}{|c|}{ Change Statistics } \\
\hline & & & & & $\begin{array}{c}\mathrm{R} \\
\text { Square } \\
\text { Chang } \\
\mathrm{e} \\
\end{array}$ & $\begin{array}{c}\text { F } \\
\text { Chang } \\
\mathrm{e} \\
\end{array}$ & df1 & df2 & $\begin{array}{c}\text { Sig. } \\
\text { F } \\
\text { Chan } \\
\text { ge } \\
\end{array}$ \\
\hline 1 & $.427^{\mathrm{a}}$ & .182 & .178 & 5.883 & .182 & 38.992 & 1 & 175 & .000 \\
\hline
\end{tabular}

1) Predictors: (Constant), Bimbingan Konseling Islam

2) Dependent Variable: Perilaku sosial

Kesimpulan:

1) Nilai $R$ adalah symbol dari koefisien korelasi sebesar 0,427 .

2) Nilai $R$ Square memperlihatkan sejauh mana interaksi variable bebas (X) terhadap variable terikat (Y). Dari table ini bias ditemukan pengaruh Bimbingan Konseling Islam (X) terhadap Perilaku Sosial peserta didik (Y2) sebesar 0,182 ataupun dapat dikatagorikan mempunyai pengaruh kontribusi 18,2\% terhadap 
Perilaku Sosial peserta didik (Y2), lainnya dipengaruhi oleh faktor lain di luar variabel $(\mathrm{X})$ atau variabel lain di luar penelitian ini atau dapat dikatakan variabel moderator sejumlah $81,8 \%$.

c. Perilaku Individu dan Sosial Peserta Didik

Tabel 24. Hasil Uji Regresi Perilaku Individu dan Sosial Model Summary ${ }^{b}$

\begin{tabular}{|c|c|c|c|c|c|c|c|c|c|}
\hline \multirow[b]{2}{*}{ Model } & \multirow[b]{2}{*}{$R$} & \multirow[b]{2}{*}{$\begin{array}{c}\mathrm{R} \\
\text { Square }\end{array}$} & \multirow[b]{2}{*}{$\begin{array}{c}\text { Adjuste } \\
\text { d R } \\
\text { Square }\end{array}$} & \multirow[b]{2}{*}{$\begin{array}{c}\text { Std. } \\
\text { Error of } \\
\text { the } \\
\text { Estimate }\end{array}$} & \multicolumn{5}{|c|}{ Change Statistics } \\
\hline & & & & & $\begin{array}{c}\mathrm{R} \\
\text { Square } \\
\text { Chang } \\
\mathrm{e}\end{array}$ & $\begin{array}{c}\text { F } \\
\text { Chang } \\
\mathrm{e}\end{array}$ & df1 & df2 & $\begin{array}{c}\text { Sig. F } \\
\text { Chang } \\
\mathrm{e}\end{array}$ \\
\hline 1 & $.458^{\mathrm{a}}$ & .210 & .205 & 5.139 & .210 & 46.400 & 1 & 175 & .000 \\
\hline
\end{tabular}

1) Predictors: (Constant), Bimbingan Konseling Islam

2) Dependent Variable: Perilaku individu dan sosial Kesimpulan:

1) Nilai R adalah symbol dari koefisien korelasi sejumlah 0,458 .

2) Nilai R Square memperlihatkan sejauhmana interaksi variable bebas $(\mathrm{X})$ terhadap variable terikat $(\mathrm{Y})$. Dari table ini bisa ditemukan pengaruh Bimbingan Konseling Islam (X) terhadap Perilaku Individu dan Sosial peserta didik (Y1 dan 2) sejumlah 0,458 ataupun bisa dikatagorikan mempunyai pengaruh kontribusi 21\% terhadap Perilaku Individu dan Sosial Peserta Didik (Y1 dan 2), lainnya dipengaruhi oleh faktor lain di luar variabel $(\mathrm{X})$ atau variabel lain di luar penelitian ini atau dapat dikatakan variabel moderator sejumlah $79 \%$.

\section{Pembahasan}

1. Pengaruh Bimbingan Konseling Islam terhadap Perilaku Individu Peserta Didik di MTsN 1 Kota Cirebon

Berlandaskan pada output korelasi diperoleh $\mathrm{r}$ hasil atau Pearson correlation sejumlah 0,412. Hal tersebut memperlihatkan bahwa nilai ini ada pada interval nilai dari korelasi antara 0,40 - 0,70 dengan kekuatan hubungan dikatagorikan sedang atau cukup berarti.Berlandaskan pada analisis ada $r$ hasil sejumlah 0,412 dan nilai $r$ tabel untuk responden visual sejumlah 177 dengan tingkat signifikansi $5 \%$ sejumlah 0,148 , maka bisa ditemukan $\mathrm{r}$ hasil $>\mathrm{r}$ tabel maupun 0,412 >0,148, maka H1 diterima dan $\mathrm{H0}$ ditolak. Melalui hasil ini memperlihatkan terdapat pengaruh Bimbingan Konseling Islam terhadap perilaku individu peserta didik.

Arti dari hasil korelasi ini yakni memperlihatkan bahwa semakin tinggi Bimbingan Konseling Islam, maka akan semakin baik juga perilaku individunya. Artinya terdapat pengaruh yang positif dan signifikan Bimbingan Konseling Islam terhadap Perilaku Individu peserta didik. Dengan demikian, bisa dijelaskan bahwa 
semakin tinggi Bimbingan Konseling yang didapatkan peserta didik, maka akan mempengaruhi secara signifikan terhadap Perilaku Individunya.

Temuan ini sejalan hasil penelitian Nanwenya (2016). Ia menemukan di sejumlah sekolah di Distrik Likoni, Kabupaten Mombasa bahwa ada banyak perilaku negatif yang dilakukan oleh para siswa seperti malas dalam belajar, kekerasan, penyalahgunaan narkotika, pergaulan bebas, dan perkelahian antar siswa. Melalui program bimbingan konseling terbukti dapat mengubah perilaku negatif siswa, meskipun hambatan pelaksanaannya begitu besar. Diantara yang cukup efektif adalah dengan pelibatan orang tua yang dipanggil ke sekolah dan menangani bersama dengan guru bimbingan konseling.

Demikian pula dengan program bimbingan konseling yang diterapkan untuk sekolah dasar dan menengah di sejumlah Negara terutama di Amerika Serikat. Penelitian menunjukkan bahwa 9000 konselor dan guru telah menerapkan program ini terhadap lebih dari satu juta siswa. Tujuan utama dari program ini adalah untuk mengembangkan keterampilan kognitif, sosial dan manajemen diri siswa. Bimbingan konseling ini memiliki delapan pilihan untuk beradaptasi dengan kebutuhan sekolah dan siswa. Salah satu pilihan tersebut adalah untuk mempersiapkan siswa untuk mengembangkan keterampilan akademik, sosial dan manajemen diri yang diperlukan untuk membuat percepatan studi ke universitas dan atau karier profesional. Dari 2003 hingga 2015, total 20 evaluasi terhadap bimbingan konseling ini dan menunjukkan dampak signifikan pada penguasaan materi pelajaran, hubungan dengan teman sebaya, komitmen terhadap sekolah dan motivasi belajar yang meningkat (Lemberger, Selig, Bowers, dan Rogers, 2015, hlm. 25-36; Brigman dan Campbell, 2003, hlm. 91-98; Coleman dan Yeh, 2011).

2. Pengaruh Bimbingan Konseling Islam terhadap Perilaku Sosial Peserta Didik di MTsN 1 Kota Cirebon

Berlandaskan output korelasi diperoleh $\mathrm{r}$ hasil atau pearson correlation sejumlah 0,427 . Hal tersebut memperlihatkan bahwa nilai ini ada pada interval nilai dari korelasi antara 0,40 - 0,70 dengan kekuatan hubungan dikatagorikan sedang atau cukup berarti. Berpijak pada analisis terdapat $r$ hasil 0,427 dan nilai $r$ tabel bagi responden Auditorial sejumlah 177 dengan tingkat signifikansi $5 \%$ sejumlah 0,148, maka bisa ditemukan $\mathrm{r}$ hasil > r tabel atau 0,427 >0,148, maka H1 diterima dan H0 ditolak. Melalui hasil ini memperlihatkan terdapat pengaruh Bimbingan Konseling Islam terhadap Perilaku Sosial peserta didik.

Arti dari hasil korelasi ini yakni memperlihatkan semakin tinggi bimbingan konseling Islam, maka akan semakin baik juga perilaku sosialnya. Dengan kata lain ada pengaruh yang signifikan dan positif Bimbingan Konseling Islam terhadap perilaku sosial. Dengan demikian, bisa disebut bahwa semakin tinggi bimbingan konseling Islam yang didapatkan peserta didik akan mempengaruhi secara signifikan terhadap perilaku sosialnya. 
Perilaku sosial adalah perilaku di antara dua atau lebih individu, dan mencakup perilaku dan interaksi apa pun di mana satu anggota mempengaruhi yang lainnya. Perilaku sosial terus berubah ketika seseorang terus tumbuh dan berkembang, mencapai berbagai tahap kehidupan. Perkembangan perilaku sangat terkait dengan perubahan biologis dan kognitif yang dialami seseorang pada waktu tertentu. Ini menciptakan pola umum perkembangan perilaku sosial pada manusia (Strain, et al, 1986). Sama seperti perilaku sosial yang dipengaruhi oleh situasi dan karakteristik individu, perkembangan perilaku juga disebabkan oleh kombinasi keduanya - temperamen anak beserta pengaturannya (Rothbart, 1994, hlm. 21-39; Whiting, 1980, hlm. 95-116).

Perilaku sosial dalam studi ini adalah perilaku peserta didik terhadap teman, guru dan orang tua. Perilaku sosial terhadap teman ialah proses timbal balik antara individu dengan kelompok sosialnya yang sebayanya (Long, et al, 2011, hlm. 186; Hossain dan Ali, 2014). Perilaku terhadap guru adalah wujud perilaku yang diperlihatkan kepada guru yang ada di sekolah ataupun di luar sekolah sebab guru dituntut untuk menggantikan peran orang tua dalam menanamkan nilai-nilai positif yang mesti dimiliki anak untuk berkembang menjadi dewasa (Barahate, 2014, hlm. 13-15; Raccah dan Elyashiv, 2008, hlm. 394-415).

3. Pengaruh Bimbingan Konseling Islam terhadap Perilaku Individu dan Sosial Peserta Didik di MTsN 1 Kota Cirebon

Berpijak pada output korelasi diperoleh $r$ hasil atau Pearson correlation sejumlah 0,458 , hal tersebut memperlihatkan bahwa nilai ini ada pada interval nilai dari korelasi antara 0,40 - 0,70 dengan kekuatan hubungan yang dikatagorikan sedang atau cukup berarti. Dari analisis terdapat $r$ hasil sejumlah 0,458 dan nilai $r$ tabel untuk responden kinestetik sejumlah 177 dengan tingkat signifikansi $5 \%$ sebesar 0,148 , maka bisa ditemukan $r$ hasil $>r$ tabel atau 0,458 > 0,148 maka $\mathrm{H} 1$ diterima dan $\mathrm{H} 0$ ditolak. Oleh karena itu, hal ini memperlihatkan terdapat pengaruh Bimbingan Konseling Islam terhadap Perilaku Individu dan Sosial peserta didik.

Berdasarkan perhitungan korelasi di atas, artinya hal ini memperlihatkan semakin tinggi Bimbingan Konseling Islam, maka akan semakin baik juga perilaku individu dan sosialnya. Dengan kata lain, terdapat pengaruh yang signifikan dan positif Bimbingan Konseling Islam terhadap perilaku individu dan sosial atau semakin tinggi Bimbingan Konseling Islam yang didapatkan peserta didik akan mempengaruhi secara signifikan terhadap peningkatan perilaku individu dan sosial. Temuan empiris ini mempertegas hasil riset yang dilakukan oleh Alegre, M. À. (2017) bahwa bimbingan konseling yang senantiasa konsisten diterapkan di sekolah bagi para siswanya akan memberikan efek positif tidak hanya terhadap prestasi akademik di sekolah tetapi juga terhadap perilaku positifnya. 


\section{SIMPULAN}

Terdapat pengaruh Bimbingan Konseling Islam terhadap Perilaku Individu peserta didik di MTsN 1 Kota Cirebon. Berpijak pada Pearson correlation sejumlah 0,412 dengan kekuatan hubungan dikatagorikan sedang atau cukup berarti. Kontribusi Bimbingan Konseling Islam terhadap Perilaku Individu ialah $17 \%$. Artinya semakin tinggi Bimbingan Konseling Islam, maka akan semakin tinggi pula Perilaku Individu peserta didik.

Terdapat pengaruh Bimbingan Konseling Islam terhadap Perilaku Sosial peserta didik di MTsN 1 Kota Cirebon. Berpijak pada Pearson correlation sejumlah 0,427 dengan kekuatan hubungan dikatagorikan sedang atau cukup berarti. Artinya semakin tinggi Bimbingan Konseling Islam, maka akan semakin tinggi pula perilaku sosial peserta didik.

Terdapat pengaruh Bimbingan Konseling Islam terhadap Perilaku Individu dan Sosial peserta didik di MTsN 1 Kota Cirebon. Berpijak pada Pearson correlation sejumlah 0,458 dengan kekuatan hubungan dikatagorikan sedang atau cukup berarti. Artinya semakin tinggi Bimbingan Konseling Islam, maka akan semakin tinggi pula Perilaku Individu dan Sosial Peserta Didik.

\section{DAFTAR PUSTAKA}

Alegre, M. A. (2017). Do Behavioral Programs Improve Pupils' Attitudes and Outcomes? "What Works in Education?" Series, no. 10. Barcelona: Ivàlua and Fundació Jaume Bofill.

Barahate, Ms.Yogini S. (2014). "Role of a Teacher in imparting Value-Education". IOSR Journal of Humanities and Social Science. 13-15.

Brigman, G. and Campbell, C. (2003). "Helping Students Improve Academic Achievement and School Success Behavior”. Professional School Counseling, vol. 7, 91-98.

Coleman, H. L. and Yeh, C. (Eds.) (2011). Handbook of school counseling. London: Routledge.

Garza, Pablo Brañas-, Antonio M. Espín, Shoshana Neuman. (2013). Effects of Religiosity on Social Behaviour: Experimental Evidence from a Representative Sample of Spaniards. Germany: Forschungsinstitut zur Zukunft der Arbeit Institute for the Study of Labor.

Hossain, F. M. Anayet, Md. Korban Ali. 2014. "Relation between Individual and Society". Open Journal of Social Sciences. Vol.02, No.08.

Lemberger, M.; Selig, J.; Bowers, H. and Rogers, J. (2015). "Effects of the Student Success Skills Program on the Executive Functioning Skills, Feelings of Connectedness, and Academic Achievement in a Predominantly Hispanic, lowincome middle School District". Journal of Counseling and Development, vol. 93, no. 1, 25-36. 
Long, Martyn, Clare Wood, Karen Littleton, Terri Passenger, dan Kiron Sheehy. (2011). The Psycchology of Education. London, New York: Routledge.

Mobarok, Ahmad. 2002. Psikologi Dakwah. Jakarta: Pustaka Firdaus.

Nanwenya, Mukhamba Mrycolette. (2016). Influence of Guidance and Counselling on the Behaviour of Students in Secondary Schools in Likoni Sub-County, Mombasa. Nairobi: Departement of Extra Mural Studies, Nairobi University.

Raccah, Audrey Addi- dan Rinate Arviv-Elyashiv. (2008). "Parent Empowerment and Teacher Professionalism". Urban Education. Vol. 43 No. 3. 394-415.

Rothbart, Mary K., Ahadi, Stephan A., Hershey, Karen L. 1994. “Temperament and Social Behavior in Childhood". Merrill-Palmer Quarterly. 40 (1), 21-39.

Strain, Phillip S., Michael J. Guralnick, dan Hill M. Walker. (1986). Children's Social Behavior: Development, Assessment, and Modification. Amsterdam, Netherlands: Elsevier.

Tuchili, Abigail Mukuwa dan Daniel Ndhlovu. (2017). "Behaviour Modification through Guidance and Counselling among Students in Selected Public Universities in Zambia: Is it Possible?." International Journal of Humanities Social Sciences and Education (IJHSSE). Vol. 4, Issue 6.

Whiting, Beatrice Blyth. (1980). "Culture and Social Behavior: A Model for the Development of Social Behavior”. Ethos. 8 (2), 95 - 116. 
40 | Kurniawan - Bimbingan Konseling Islam ... 